\title{
Research on Innovation and Entrepreneurship Education Reform in Vocational Colleges
}

\author{
Shenghui Qu \\ The School of Film and Television Art, Hunan Mass Media Vocational and Technical College, Changsha, China \\ Email address: \\ 38777058@qq.com

\section{To cite this article:} \\ Shenghui Qu. Research on Innovation and Entrepreneurship Education Reform in Vocational Colleges. International Journal of Secondary \\ Education. Vol. 9, No. 2, 2021, pp. 51-56. doi: 10.11648/j.ijsedu.20210902.13
}

Received: April 27, 2021; Accepted: May 10, 2021; Published: May 14, 2021

\begin{abstract}
At in 2014, Premier Li put forward the call of "mass entrepreneurship and innovation" for the first time, and wrote the term "mass entrepreneurship and innovation" into the 2015 government work report as never before. Since that time, the new situation of "everyone innovation" and "mass innovation" has become popular throughout the country. As the backbone of high-quality skilled personnel training, vocational colleges should correctly understand the employment needs of society and the country, gradually create an innovation and entrepreneurship education environment, and better cultivate and educate students, promote students to become excellent skilled talents gradually. In this context, vocational colleges across the country have carried out innovation and entrepreneurship education, aiming to improve students' innovation ability and learning initiative and enthusiasm on the basis of mastering certain professional skills. In view of the poor effect of innovation and entrepreneurship education reform in China's vocational colleges at the present stage, this paper expounds the necessity of improving the innovation and entrepreneurship ability of vocational college students in the "double innovation" environment, analyzes the current situation of innovation and entrepreneurship education, and puts forward some ways to improve the innovation and entrepreneurship education of vocational college students combined with the teaching characteristics of higher vocational education, In order to improve the practical ability of innovation and Entrepreneurship of higher vocational students.
\end{abstract}

Keywords: Vocational Colleges, Innovation and Entrepreneurship Education, Present Situation, Channel

\section{Introduction}

In the "higher education in the $21 \mathrm{st}$ century: world declaration of vision and action", the United Nations clearly put forward: "entrepreneurial skills and entrepreneurship must be regarded as the basic goal of higher education". In this context, in order to promote the better and faster development of China's education, it is very necessary to continuously improve the level of vocational education [1]. As the backbone of high-quality skilled personnel training, vocational colleges should correctly understand the employment needs of society and the country, gradually create an innovation and entrepreneurship education environment, and better cultivate and educate students, promote students to become excellent skilled talents gradually. In this context, vocational colleges across the country have carried out innovation and entrepreneurship education, aiming to improve students' innovation ability and learning initiative and enthusiasm on the basis of mastering certain professional skills. But at present, most of the innovation and entrepreneurship education still adopts the traditional teaching method, which is not integrated with the professional courses, and the practicality is not strong, which affects the effectiveness of innovation and entrepreneurship education [2-3].

\section{Overview of the Concept of "Innovation and Entrepreneurship"}

At the 2014 Summer Daswo Forum, Premier Li put forward the call of "mass entrepreneurship and innovation" for the first time, and wrote the term "mass entrepreneurship and innovation" into the 2015 government work report as never before. Since then, the new situation of "everyone innovation" and "mass innovation" has become popular throughout the country. In May 2015, the General Office of the State Council issued the implementation opinions on 
deepening the reform of innovation and entrepreneurship education in Colleges and universities [3]. In the overall goal, it clearly mentioned the requirements of innovation and entrepreneurship education reform in the next five years. The report of the 18th and 19th National Congress of the Communist Party of China also fully reflects the state's concern for the innovation and entrepreneurship education of college students, requiring colleges and universities to attach great importance to the education and guidance of college students' innovation and entrepreneurship, and supporting the introduction of a series of relevant policies to enhance the innovation and entrepreneurship ability of college students. It can be seen that innovation and entrepreneurship is the historical mission given to college students by the times. Under the inspiration of the "double innovation" era, cultivating college students' innovation and entrepreneurship ability has become an inevitable requirement of social development [4].

\section{The Necessity of Innovation and Entrepreneurship Education in Vocational Colleges}

\subsection{Innovation and Entrepreneurship Education Is the Basis of Improving Students' Employability}

Innovation and entrepreneurship education is the basis of improving students' employability. The popularization of higher education subverts the traditional concept of employment, which requires graduates not only to have strong professional ability, but also to have the employability and comprehensive quality required by the talent market. In this way, students can not only get better employment, but also play a full role in society and enterprises. Of course, in order to make students have strong employability and comprehensive quality, vocational colleges need to attach great importance to and carry out innovation and entrepreneurship education with high quality, organize students to carry out a series of innovation and entrepreneurship education activities, and let students try to use basic theory to solve practical problems, divergent thinking and exercise ability in practice, Only in this way can students' competitive power be gradually enhanced [5].

\subsection{Innovation and Entrepreneurship Education Is the Inevitable Requirement of Socialist Development}

With China's economy entering the new normal, the employment demand of enterprises, society and even the country is increasing, and there are higher requirements for talent employment [6]. In this case, in order to enable students to meet the employment standards of enterprises and society, make contributions to enterprises, society and even the country, and promote socialist development, vocational colleges should correctly understand the talent requirements required by the current society, analyze the shortcomings of education and teaching at this stage, and promote innovation and entrepreneurship education, In this way, we can carry out a series of theme activities according to the students' majors, cultivate the students in technology, management, operation and innovation, promote the students' all-round development, make the students gradually become innovative talents, and meet the needs of social employment. From this point of view, innovation and entrepreneurship education is the inevitable requirement of socialist development [7].

\subsection{Carrying out Innovation and Entrepreneurship Education Is an Important Part of Deepening the Teaching Reform in Vocational Colleges}

Based on the reality, this paper analyzes the actual situation of talent cultivation in vocational colleges at this stage, and it is not difficult to find that the education and teaching activities carried out by vocational colleges do not meet the needs of the talent market, which leads to the lack of students' employability and even affects the future development of students. To effectively carry out innovation and entrepreneurship education in vocational colleges, the education can optimize and adjust teaching resources from the perspective of students' service ability and employment ability, teach and train students with pertinence, continuously strengthen students' professional level, improve students' basic ability and enhance students' comprehensive quality. This is of great help to students' better growth and development in the future, and also can promote the deepening reform of teaching work in vocational colleges [9].

\section{Current Situation of Innovation and Entrepreneurship Education in Vocational Colleges}

\subsection{Lack of Attention to Innovation and Entrepreneurship Education}

At present, some higher vocational colleges do not have a good understanding of college students' innovation and entrepreneurship education ideas, and lack of relevant supporting policies and funding support. Innovation and entrepreneurship education to a large extent cannot meet the development needs of higher vocational students' innovation and entrepreneurship ability. Due to the constraints of venues and funds, professional entrepreneurship education basic practice platform and project incubation base have not been established and improved, resulting in innovation and entrepreneurship education as a mere formality. It still stays in the form of innovation and entrepreneurship theory, concept explanation, policy interpretation, innovation and entrepreneurship lectures, and has not really played a role in improving entrepreneurship practice ability [8].

\subsection{Single Innovation and Entrepreneurship Curriculum}

At present, many vocational colleges pay more attention to the cultivation of students' professional knowledge and skills, 
the cultivation of students' innovation and entrepreneurship consciousness is not systematic and scientific, and the content of innovation and entrepreneurship course is not rich. Some vocational colleges combine entrepreneurship course and employment course into a compulsory course. Although they have completed the teaching requirements, there are few hours of innovation and entrepreneurship course in the training program [10]. The course mainly includes innovation and entrepreneurship thinking, innovation and entrepreneurship projects, innovation and entrepreneurship team and other general knowledge points, lack of professional and technical knowledge, and the course content is single. At the same time, the basic education of innovation and entrepreneurship is mainly carried out in the form of online courses, and there is a lack of offline practice teaching of entrepreneurship and innovation combined with specific cases, so the course form is single. Students' awareness of innovation and entrepreneurship cannot be trained and teaching effect cannot be achieved, which is not conducive to the development of innovation and entrepreneurship education.

\subsection{Professional Innovation and Entrepreneurship Education Teachers Are Insufficient}

The shortage of full-time teachers of innovation and entrepreneurship education in vocational colleges, on the one hand, is because most of the teachers in charge of innovation and entrepreneurship education in vocational colleges are economic management teachers, or counselors, who are lack of innovation and entrepreneurship related experience, and lack of systematic innovation and entrepreneurship theory training. Innovation and entrepreneurship education is a practical subject. If teachers do not have relevant experience, it is difficult to give effective guidance to students' innovative ideas, and cannot effectively drive students' entrepreneurial enthusiasm. On the other hand, although many professional teachers have enterprise experience and understand both professional innovation and enterprise operation, they do not show enough participation in innovation and entrepreneurship education. They lack participation consciousness and provide less support for students' innovation and entrepreneurship projects from innovation cultivation to entrepreneurship landing.

\subsection{Lack of Integrated Innovation and Entrepreneurship Practice Platform}

At present, the innovation and entrepreneurship education in vocational colleges is still in its infancy, and the innovation and entrepreneurship practice platform constructed by vocational colleges is lack and unsystematic. According to the survey, most schools have built their own entrepreneurial practice park, but the scale is small and the number of places is small, which cannot well support the students' entrepreneurial practice, resulting in the lack of systematic innovative thinking stimulation and entrepreneurial practice model. Although many schools have set up innovation and entrepreneurship offices and innovation and entrepreneurship colleges to manage entrepreneurship and entrepreneurship projects separately, they generally stay in the stage of collecting and managing projects. They usually lack substantive guidance for the guidance, polishing and implementation of projects. They need to build an integrated innovation and entrepreneurship training platform that fits the reality of innovation and entrepreneurship projects and the needs of students, Build a link between school innovation and entrepreneurship management and students' innovation and entrepreneurship practice.

\section{Suggestions on the Reform of Entrepreneurship and Innovation Education in Vocational Colleges}

The reform of innovation and entrepreneurship education in vocational colleges is a systematic project. Each college should do a good job in the top-level design and optimize the implementation plan as a whole. Efforts should be made to solve the problems encountered in the implementation and do a good job in the reform of innovation and entrepreneurship education.

\subsection{Unified Understanding, Clear Innovation and Entrepreneurship Education Personnel Training Objectives}

The aim of talent training should be clarified, and the problems of "boss and entrepreneur quick class" caused by the concept barrier should be solved, which seriously hinders the training and promotion of entrepreneurship quality of all students. It is clear that the ultimate goal of cultivating "innovation and entrepreneurship" talents is to promote students' all-round development, build innovative culture, enhance national spirit, and build an independent and innovative country; The purpose of education is to cultivate the students' enterprising and pioneering spirit, to enhance their innovative spirit, entrepreneurship awareness and ability of innovation and entrepreneurship, and to increase the students who are engaged in entrepreneurship practice. The phased goal is to establish and improve the innovation and entrepreneurship education system of colleges and universities by 2020 , which includes classroom teaching, independent learning, combination of practice, guidance and assistance, and cultural guidance, and the quality of talent training will be significantly improved. To cultivate the students with the creative comprehensive quality that meets the needs of the knowledge economy and information age, namely, they should consciously predict changes, actively respond to changes, dare to grasp opportunities and strive for the quality and ability of enterprising; To cultivate students' entrepreneurial spirit, entrepreneurial consciousness and entrepreneurial autonomy, the key lies in the cultivation of consciousness, spirit and ability. 


\subsection{Establish an Organization and Build a Team of Innovative and Entrepreneurial Teachers}

Colleges and universities should set up specific management departments for innovation and entrepreneurship, such as entrepreneurship education research center, entrepreneurship practice center, etc. Set up specialized personnel, build a platform for school enterprise cooperation, innovation and entrepreneurship, and solve the problem of scarce resources for entrepreneurship and innovation.

On the one hand, we should strengthen the quality of innovation and entrepreneurship education for the existing teachers, and cultivate the entrepreneurial practice of teachers On the basis of school enterprise cooperation, higher vocational colleges can send backbone teachers or teachers with entrepreneurial intention and ability to the front line to cultivate their market awareness, or invite experts to the school for training to increase the entrepreneurial practice of these teachers. On the other hand, it is necessary to employ part-time instructors for entrepreneurial practice activities to make up for the lack of practical teachers. These part-time teachers can be composed of successful entrepreneurs, experts of government economic departments, experts of engineering technology, experts of economic management, management experts of incubators, venture capitalists and lawyers, so as to form a diversified teaching team of different levels. The idea and knowledge of innovation and entrepreneurship will be gradually infiltrated into all the courses of the school, enrich and improve the curriculum knowledge structure of teachers' innovation and entrepreneurship education, and incorporate it into the overall planning of the construction of university teachers.

\subsection{Curriculum System of $R \& D$ and Entrepreneurship}

Therefore, it is the key to construct the curriculum system of innovation and entrepreneurship education which is organically integrated with professional education and matched with innovative talents. The purpose of education is to cultivate students' entrepreneurial concept, entrepreneurial spirit, entrepreneurial thinking and entrepreneurial ability, not just to impart entrepreneurial knowledge and skills. Therefore, first of all, take all students as the object of education, set up entrepreneurship general education courses, cultivate students' entrepreneurial consciousness and spirit, from the perspective of popularizing the basic knowledge of innovation and entrepreneurship, so that every student can understand innovation and entrepreneurship, and have a certain understanding of innovation and entrepreneurship. Secondly, we should integrate entrepreneurship education into professional education, integrate it with professional education, and cultivate students' innovation and entrepreneurship skills and awareness in practice class. Finally, in the community activities and extracurricular cultural activities, the elements of innovation and entrepreneurship are embedded, such as simulated business competition, "Challenge Cup" entrepreneurship competition, etc. In short, vocational colleges design different entrepreneurship courses according to different levels of students and their own resources to meet the cultivation of students' innovation and entrepreneurship goals.

\subsection{Build Entrepreneurial Platform and Encourage Entrepreneurial Practice}

The realization of college students' innovation and entrepreneurship education practice resources is mainly through the integration of various resources of schools, enterprises and society, and the establishment of an open and diversified entrepreneurship practice platform and base. Due to the limited resources in the school, the school should actively cooperate with enterprises, the government and the pioneer park to realize sharing, promote each other in technology and make efficient use of funds, so as to create an innovation and entrepreneurship training platform for students.

\section{Strategies to Promote and Restrict the Innovation and Entrepreneurship Education Reform}

\subsection{Strengthen Publicity to Enhance Students' Recognition of Innovation and Entrepreneurship}

"The ultimate goal of innovation and entrepreneurship education lies in students. Only when students accept the concept of innovation and entrepreneurship and dare to practice innovation and entrepreneurship, can we say that innovation and entrepreneurship education has played a practical effect." Therefore, we must focus on the construction of campus innovation and entrepreneurship culture. As an important part of the cultural construction of students, we should make full use of the resources inside and outside the school, carry out various forms of "innovation and entrepreneurship" education theme activities, hold relevant "innovation and entrepreneurship" lecture forums, create a strong innovation and entrepreneurship campus cultural atmosphere, and stimulate students' innovation and entrepreneurship consciousness.

We should strengthen the publicity of the value of innovation and entrepreneurship and the advanced models of graduates' innovation and entrepreneurship, guide the students' innovation and entrepreneurship, and stimulate their enthusiasm for innovation and entrepreneurship. Publicize the relevant policies and information of innovation and Entrepreneurship with the official account of micro-blog, WeChat and so on. In the form of window, large posters for publicity or regular invitation to face-to-face talks and exchanges between vocational innovation and entrepreneurship winners and students. Change the students' passive teaching mode of thinking on innovation and entrepreneurship, and make them actively eager to participate in the training courses and practical learning of innovation and entrepreneurship. 


\subsection{Strengthen the Construction of Teaching Staff and Improve the Teaching Ability of Teachers' Innovation and Entrepreneurship Education}

It is necessary to clarify the teaching ability requirements of teachers' innovation and entrepreneurship education, improve the construction of innovation and entrepreneurship education teachers, formulate the admission system and training service mechanism of innovation and entrepreneurship education teachers, strengthen the cultivation of teachers' innovation and entrepreneurship education theory and practice ability, establish the innovation and entrepreneurship education teacher training center, and combine with teachers' own professional classification and training service mechanism systematic innovation and entrepreneurship teacher training should be carried out at different levels to enhance teachers' innovation and entrepreneurship teaching practice ability. The specific measures can be referred to as follows: (1) give full play to the central role of teachers' teaching development, and improve the education and teaching awareness and ability of innovation and entrepreneurship teachers through various forms of teaching training and practical activities, such as backbone training, famous teachers' lecture hall, enterprises and so on (2) The establishment of teachers' studio, relying on the innovation and Entrepreneurship Education Studio for college students, encourages teachers to actively organize and apply for a number of innovation and entrepreneurship education research projects, so as to promote the innovation and entrepreneurship education and ability of college students (3) Establish a talent pool of excellent innovation and entrepreneurship tutors. Famous experts, entrepreneurs, successful entrepreneurs and other industry alumni and talents are invited to serve as innovation and entrepreneurship tutors or part-time teachers.

\subsection{Promote Collaborative Education and Promote the Organic Integration of Innovation and Entrepreneurship and Professional Education}

"The Ministry of Education requires deepening the reform of innovation and entrepreneurship education in colleges and universities, and realizing the transformation of innovation and entrepreneurship education and professional education from" two skins to "organic integration". Therefore, we should promote collaborative education, promote the collaboration between talent training and social needs, give full play to the advantages of industry, university and research in teaching resources and talent training, and promote the combination of innovation and entrepreneurship theory and practical education. Establish the innovation and entrepreneurship education mode based on professional education, take innovation and entrepreneurship education as a professional compulsory course, so that students can master the knowledge of entrepreneurship related management, business, tax, investment, law and so on. To clarify the objectives of innovation and entrepreneurship education and reform the assessment methods of innovation and entrepreneurship education, we can implement the credit transfer, credit reward and suspension system of innovation and entrepreneurship, explore the education mode and path combined with the characteristics of different majors, and realize the diversified innovation and entrepreneurship education mode, so as to meet the entrepreneurial needs of students of different majors.

Open courses of innovation and entrepreneurship education and excellent online open courses of resource sharing are set up to enrich the curriculum resources of innovation and entrepreneurship education. We should strengthen the practice of innovation and entrepreneurship, create a practical training platform for school enterprise cooperation, and actively participate in various kinds of innovation and entrepreneurship competitions, such as "Internet + " innovation and entrepreneurship competition, college students' service outsourcing innovation and entrepreneurship competition, and "College Students' Innovation and Entrepreneurship Training Plan" to effectively improve students' practical ability, To realize the transformation of talent training from single discipline to multi discipline integration, and promote the close connection between talent training and economic and social development, innovation and entrepreneurship needs.

\subsection{Build the System of Government School Enterprise Joint Innovation and Entrepreneurship to Enhance the Practical Ability of Innovation and Entrepreneurship}

Adhere to the market demand orientation, strengthen the top-level design, and build a government school enterprise joint innovation and entrepreneurship system. Under the guidance of government policies, vocational colleges and enterprises should deeply participate in and cooperate with each other, give full play to the advantages of the college in teaching resources and personnel training, integrate various resources, increase the support for entrepreneurship practice base, and build up college students' innovation and entrepreneurship training base, innovation and entrepreneurship park and entrepreneurship incubation base, It focuses on cultivating innovative and entrepreneurial talents with excellent theoretical basis and practical skills. We should increase the special funds for students' independent innovation and entrepreneurship, promote the cooperative innovation of complementary resources, build a cooperation platform, and realize technology exchange and talent mutual assistance through regular docking meetings, so as to improve the practical ability of innovation and entrepreneurship talents.

\section{Summary}

"Deepening the reform of innovation and entrepreneurship education in Colleges and universities is an important measure for the country to implement the innovation driven development strategy, promote the comprehensive reform of higher education, and promote higher quality entrepreneurship and employment of college graduates." The 
reform of innovation and entrepreneurship education in vocational colleges is faced with many factors, such as the level of leadership and management needs to be improved, the level of innovation and entrepreneurship education curriculum design and teachers need to be improved, and the link of industry, learning and research innovation and entrepreneurship chain is not smooth. Vocational education with the goal of cultivating high-quality skilled talents should play an important role in "entrepreneurship and innovation" education. It should focus on cultivating students' innovative spirit, promote the organic integration of innovation and entrepreneurship education and professional education, increase the strength of school enterprise cooperation, build a government school enterprise joint innovation and entrepreneurship system, and effectively improve students' entrepreneurial practice ability.

\section{Conflicts of Interest}

The author declares that he have no competing interest.

\section{References}

[1] Liu C. H, Li X. H, Li G, Yue Q. R, Ren Y. G (2014) Practice and Exploration of the Undergraduate Innovation and Entrepreneurship Training Program. Research and Exploration in Laboratory, 33(5): 163-166.

[2] Xu X. H, Huang D. Q, Xiao H. X (2020) On the Employment Satisfaction of College Students from the Perspective of "Mass Entrepreneurship and Innovation" Education. Education and Vocation, 17: 67-72.
[3] Sun D (2020) Research on the construction of innovation and entrepreneurship education practice system integrated with professional education. Technology \& Innovation, 21: 151-152.

[4] Sun W. Q, Meng C. Y, Wang W. J (2020) A Study on the Curriculum System for the Cultivation of Innovation and Entrepreneurship Ability in Application-oriented Universities. Modern Education Management, 7: 75-81.

[5] Zhang Y, Wang S. M, Wang X (2020) Research on the Path of Cultivating College Students' Innovation and Entrepreneurship. Value Engineering, 39 (10): 278-279.

[6] Yao Y. Q (2020) Innovation and Promotion of College Students' Entrepreneurship in China. Journal of China Institute of Industrial Relations, 34 (2): 19-26.

[7] Zhang S, A (2020) On the integration of innovation and entrepreneurship education and professional education in local colleges and Universities. Education Forum, 40: 206-208.

[8] Xie C. H, Cheng Y. B, Xi L (2020) Practical exploration of integrating innovation and entrepreneurship education into professional education in the new era. Journal of Mudanjiang College of Education, 10: 33-35.

[9] Yan Y (2015) Teaching Research on Higher Vocational Pre-School Education of Professional Art Course Based on Innovation and Entrepreneurship Education. Creative Education, 5: 12-14.

[10] Zhang S. X, Wang Y. W, Liu X. L, Wang H. L (2011) Cultivating Entrepreneurial Talents of Sericulture under the Guidance of Specialty Expansion. China Agricultural Education, 5: 82-85. 